\title{
Finance And Poverty Reduction In China: An Empirical Investigation
}

Sin-Yu Ho, University of South Africa, South Africa

Nicholas M. Odhiambo, University of South Africa, South Africa

\begin{abstract}
In this paper, the causal relationship between financial development and poverty reduction is examined in China, using the newly developed ARDL-Bounds testing procedure. The paper uses two proxies of financial development against private per capita consumption - a proxy for poverty reduction to examine this linkage. The results of the study show that the causal relationship between financial development and poverty reduction is sensitive to the proxy used to measure the level of financial development. When the domestic credit to the private sector $(D C P / G D P)$ is used as a proxy for financial development, a bidirectional causality is found to prevail between financial development and poverty reduction in the short run. However, when the broad money supply ratio $(\mathrm{M} 2 / \mathrm{GDP})$ is used as a proxy, a bidirectional causality between financial development and poverty reduction is found to prevail in the short run, but a unidirectional causal flow from poverty reduction to financial development is found to predominate in the long run. These results show that the poverty-reduction programmes, which have been ongoing in China for decades, are likely to lead to further development of the financial sector in the long run.
\end{abstract}

Keywords: China; Poverty Reduction; Financial Development; ARDL-Bounds Test

\section{INTRODUCTION}

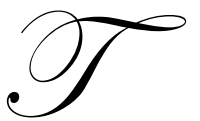

he relationship between financial development and poverty reduction has generated a substantial body of literature from both theoretical and empirical fronts in recent years. Studies have shown that financial development may result in poverty reduction by enhancing economic growth. This view is consistent with the so-called "trickle-down" mechanism. Although some previous studies argue in favour of a trickle-down effect between financial development and poverty reduction, a number of studies maintain that financial sector development can only contribute to poverty reduction up to a certain threshold level of economic development (see Jeanneney and Kpodar, 2005). Unfortunately, very few studies have examined the dynamic relationship between financial development and poverty reduction, using modern econometric techniques. Moreover, some of these studies have mainly used cross-section data analysis, which may not satisfactorily address country-specific issues. In other words, by lumping together data from different countries, the cross-sectional data analysis cannot satisfactorily capture the country-specific effect of financial development on poverty reduction, or vice versa (see Odhiambo, 2008, 2010a). In addition, some of the previous studies have mainly used the residualbased cointegration test associated with Engle and Granger (1987) and the maximum likelihood test based on Johansen and Juselius (1990) to examine the long-run relationship between financial development and poverty reduction. Yet, it is now clear that these techniques may be inappropriate when the sample size is too small (see Narayan and Smyth, 2005; Odhiambo, 2009a).

The current study, therefore, aims to examine the causal relationship between financial development and poverty reduction in China, using the recently developed ARDL- bonds testing approach. The study also uses two proxies of financial development; namely, the ratio of broad money supply to GDP (M2/GDP) and the domestic credit to the private sector as a ratio of GDP (DCP/GDP). 


\section{FINANCIAL DEVELOPMENT AND POVERTY DYNAMICS IN CHINA}

\section{Financial Development in China}

China began its economic reform in the late 1970s and has made substantial progress in this regard over the past three decades. The pre-reform mono-bank system has been transformed into a more sophisticated and diversified financial system. The financial sector currently consists of the central bank (also known as the People's Bank of China), policy banks, commercial banks, non-bank financial institutions, insurance companies, two stock markets and a bond market, amongst others. China's banking sector is heavily concentrated around the big four state-owned banks; namely, the Bank of China (BOC), the China Construction Bank (CCB), the Industrial and Commercial Bank of China (ICBC) and the Agricultural Bank of China (ABC).

During the 1980s, China pursued a number of financial sector reforms, which were characterised by a process of revitalization of banking institutions. This resulted in a rapid diversification of the financial sector, which led to the growth of a number of financial intermediaries outside of the big four state-owned banks. For example, regional banks were formed in the Special Economic Zones in the coastal areas; a network of Rural Credit Cooperatives (RCCs) was setup under the supervision of the Agricultural Bank of China, while Urban Credit Cooperatives (UCCs) were also set up in the urban areas. Non-bank financial intermediaries, such as the Trust and Investment Corporations (TICs), operated in selected banking services and non-banking services, with restrictions on both sources of deposit and loans made, emerged and proliferated during this period (see also Allen et al. 2005).

Since 1994 a series of major banking reforms has taken place (see Hasan and Zhou 2006). These include, amongst others: 1) establishment of three policy banks in 1994, which include the State Development Bank, the Agricultural Development Bank, and the Export-Import Bank of China; 2) transformation of the urban credit cooperative into a commercial bank, which took place during 1996-1998; 3) granting licenses to non-state commercial banks; 4) granting licenses to some foreign banks; 5) reduction of government intervention in the credit allocation; and 6) loosening the controls on interest rates, etc.

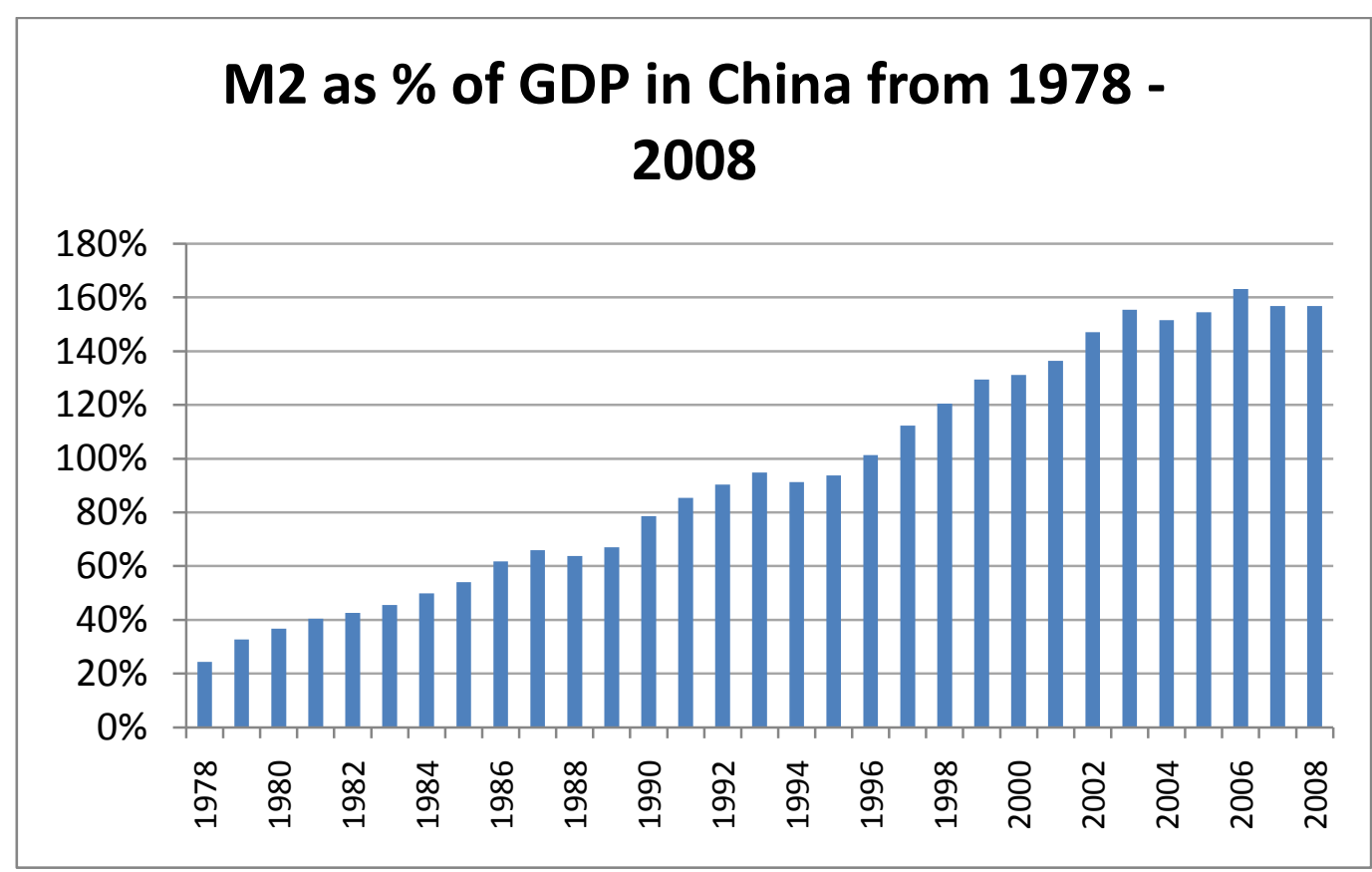

Figure 1: The Trend of M2 as a \% of GDP in China During the Period 1978-2008 Source: World Deveopment Indicators (2009) 
The banking sector has been playing an important role in supporting the economic growth in China and has experienced remarkable growth during the last three decades. Since the early 1980s, the financial depth in China has been impressive, with the real monetary balance growing at a rate faster than the real economy. The monetization ratio (i.e. the ratio of M2 to GDP) increased from 24 percent in 1978 to 146 percent in 2008. The remarkable financial deepening is primarily due to two factors - the monetization of the economy and, most importantly, the expansion of household savings. In 2001, household deposits accounted for $77.9 \%$ of quasi-money and $47.2 \%$ of M2 (Hao, 2006). Given the steady growth of the economy, the sharp increase in personal income and limited investment opportunities, the total bank deposits from individuals have been growing very fast since the mid-1980's. Such a high level of financial depth places China among the most advanced economies. Figure 1 shows the trend of M2 as a percentage of GDP during the period 1978-2008.

\section{Poverty Dynamics in China}

Just as in the case of its financial development, China's progress regarding poverty reduction over the last three decades is remarkable. In terms of a wider range of indicators, the progress has been impressive. By China's official poverty standard of RMB 300 per person per year at 1990 prices, the poverty headcount ratio in rural China declined from $18.5 \%$ in 1981 to $2.8 \%$ in 2004 and the number of rural poor fell from 152 million to 26 million (World Bank, 2009). Measured by the new international poverty standard of $\$ 1.25$ per person per day using the 2005 Purchasing Power Parity for China, the poverty headcount ratio fell from $84 \%$ in 1981 to $16 \%$ in 2005 , which is also striking (World Development Indicators, 2009). The country's social indicators have improved significantly since the economic reforms. For example, the average life expectancy at birth increased from 66 in 1980 to 73 in 2003. The infant mortality rate is currently 18 , as compared to 46 in 1980 . The adult literacy rate improved from $66 \%$ in 1982 to $94 \%$ in 2008 (World Development Indicators, 2009). Poverty in China has been considered to be primarily a rural phenomenon due to huge per capita income disparity between the rural and urban populations. At the beginning of the $1980 \mathrm{~s}$, absolute poverty in the urban population was $0.3 \%$ as compared to $28 \%$ of the rural population (World Bank, 2004).

However, due to various economic reforms, the incidence of rural poverty dropped from $30.7 \%$ in 1978 to 1.6\% in 2007 (UNDP, 2008). According to the China Human Development Report 2008, China's poverty reduction policies can be roughly classified into four phases.

\section{Phase 1 - Rural Reform (1978-1985)}

This period saw the institutional reforms of the rural production, distribution systems, and procurement prices. The fundamental institutional change was the land reform, characterized by the implementation of the household contract responsibility system in rural China which greatly stimulated farmers' incentive for economic activity. The reforms delivered remarkable results in poverty reduction. Their per capita net income grew at an annual rate of $16.5 \%$. By China's official poverty standard, the headcount in rural China declined rapidly from 250 million in 1978 to 125 million in 1985 . This was the period of the most rapid decline in poverty incidence in China (UNDP, 2008).

Phase 2 - National Targeted Poverty Reduction Programs (1986-1993)

During this period, the Chinese government established specialized agencies and special funds for targeted rural poverty reduction programs. By 1994, 80 million of the rural population remained poor, lowered by 45 million compared to 1985 (World Bank, 2004; UNDP, 2008).

Phase 3 - The 8-7 Plan (1994-2000)

The Chinese government introduced the 8-7 Plan, aspiring to lift the majority of the remaining 80 million poor above the official poverty line during the seven-year period (1994-2000). China's anti-poverty plan was elevated to a national strategy with greater determination and increased anti-poverty efforts. As a result, the number of rural poverty-stricken people fell from 80 million in 1994 to 32 million in 2000 (World Bank, 2004; UNDP, 2008). 
Phase 4 - New Century Rural Poverty Alleviation Plan (2001-2010)

This period saw important policy shifts to balance development gains between urban and rural areas and across different regions. In 2001, China's Rural Poverty Reduction and Development Compendium (2001-2010) was formed and issued. With strategies for building the new countryside, developing the western and central regions, China has pursued a balanced anti-poverty strategy. As a result, the number of rural poor has continued to fall, from 30 million in 2001 to 15 million in 2007 (UNDP, 2008). Figure 2 shows the trend of total poverty headcount ratio in China during the period 1981-2005, while Figure 3 shows the trend of rural poverty incidence in China during the period 1984-2007 as compared to 1978.

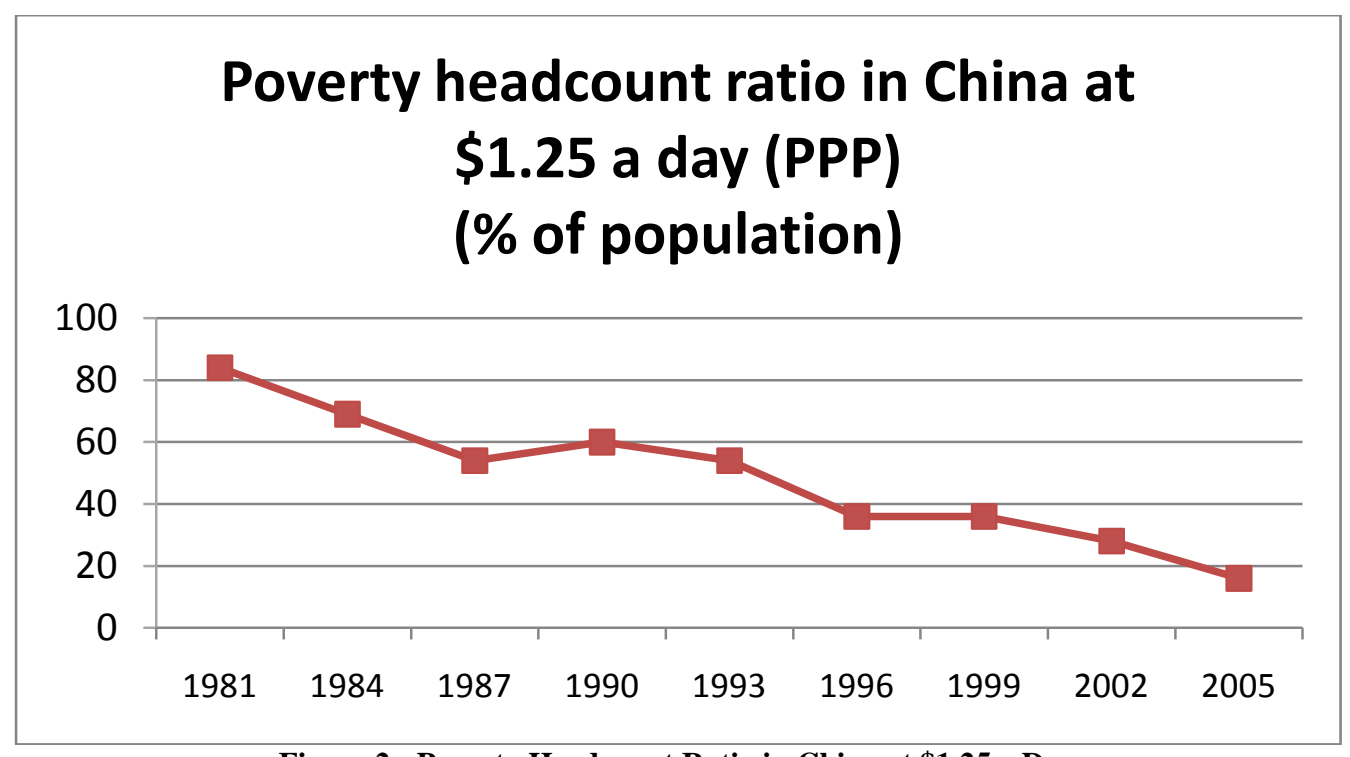

Figure 2: Poverty Headcount Ratio in China at \$1.25 a Day

Source: World Development Indicators (2009)

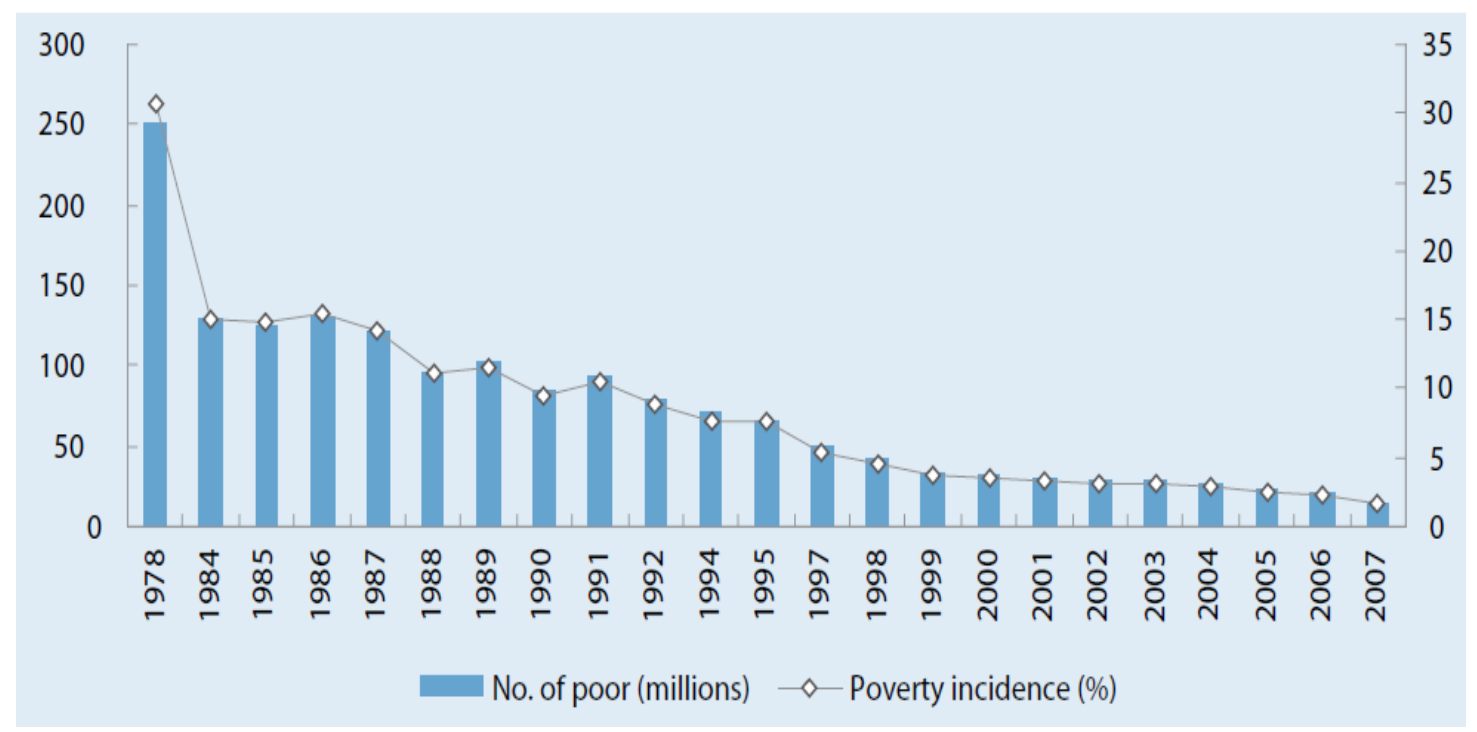

Figure 3: China's Incidence of Rural Poverty, 1978-2007

Source: UNDP (2008) 


\section{LITERATURE REVIEW}

Theoretically, financial development can directly contribute to poverty reduction in different ways (see Odhiambo, 2010b). Firstly, financial development can improve the opportunities for the poor to access formal finance by, inter alia, reducing the cost of lending to small borrowers (see also Stiglitz, 1998; Jalilian and Kirkpatrick, 2002). Secondly, financial development enables the poor to access financial services, thereby enabling the poor to achieve a sustainable livelihood (see World Bank, 2001; Jalilian and Kirkpatrick, 2002). It is also worth noting that financial development may trickle down to the poor through its influence on economic growth. This is largely due to the implied positive relationship between financial development and economic growth.

Although financial sector development has a direct impact on poverty reduction, very few studies have examined the direction of causality between financial development and poverty reduction. Some of the countryspecific studies that have attempted to examine the relationship between financial sector development and poverty reduction include Park et al. (2004), Jiang and Yan (2006), Bittencourt (2010), Odhiambo (2010a), Odhiambo (2010b), Geda et al (2006), Quartey (2005), Husain (2004), and Burgess and Pande (2003), amongst others. Park et al. (2004), for example, while assessing the potential role of micro-finance for poverty alleviation and financial reform in China, find that the success of China's micro-finance movement that began in 1994 is somewhat mixed. Jiang and Yan (2006) examine the effectiveness of civilian credit in anti-poverty programmes in China's rural areas. Using the static grey-relevancy and forward-moving dynamic grey-relevancy matrix, the results indicated that civilian credit can relieve rural poverty effectively in China. The authors recommend that both the normal finance market and the civilian finance market should be improved in order to promote anti-poverty effectively. The authors also recommend that the rural economic structure should be optimized. Bittencourt (2010), while examining the impact of financial sector development on earning inequality in Brazil in the 1980s and the first half of the 1990s, finds that a broader access to financial and credit markets had a significant and robust effect in reducing inequality. Odhiambo (2010a), while examining the inter-temporal causal relationship between financial sector development and poverty reduction in Zambia, using an autoregressive distributed lag (ARDL)-bounds testing procedure, finds that the casual relationship between financial development and poverty reduction is sensitive to the proxy used for measuring the financial development. Odhiambo (2010b) uses a tri-variate causality test to examine the intertemporal causal relationship between financial development and poverty reduction in Kenya during the period 19682006. The study finds a distinct causal flow from financial development to poverty reduction, irrespective of whether the causality is estimated in the short run or in the long run. The authors conclude that financial sector development in Kenya is pro-poor and pro-savings. Geda et al. (2006), while using the household panel data of Ethiopia during the period 1994-2000, find that access to finance is an important factor in consumption smoothing and hence poverty reduction. Quartey (2005), while investigating the relationship between financial sector development and poverty reduction in Ghana, finds that even though financial sector development does not Grangercause savings mobilization in Ghana, it induces poverty reduction. Husain (2004) notes that the financial sector reforms - initiated in the late 1990s in Pakistan - created a favourable environment in which the poor and the middle class have a better chance of receiving credit from formal institutions. Burgess and Pande (2003) use rural bank branch data from India to capture the direct impact of access to financial services on poverty. Their estimates suggest that a 1 percent increase in the number of rural locations banked per capita reduced rural poverty by 0.42 percent and increased total output by 0.34 percent.

Apart from the above country-specific studies, there are also some cross-country studies that have attempted to examine the relationship between financial development and poverty reduction. These include Akhter et al. (2010), Jeanneney and Kpodar (2008), Claessens and Feijen (2006), Honohan (2004), Beck et al. (2004), Jalilian and Kirkpatrick (2005), Jalilian and Kirkpatrick (2002), and Li et al. (1998), amongst others. Akhter et al. (2010), for example, employs a panel-data estimation technique, called fixed-effect vector decomposition, on 54 developing countries to explain poverty in terms of financial development and financial instability. Their results indicate a strong correlation between the level of financial development and financial instability, suggesting that financial development helps the poor, to a larger extent, in countries with stable financial systems. Jeanneney and Kpodar (2008) investigate how financial development helps to reduce poverty directly, through the McKinnon conduit effect, and indirectly through economic growth. The results obtained with data from a sample of developing countries during the period 1966-2000 suggest that the poor benefits from the ability of the banking system to facilitate transactions and provide savings opportunities, but to some extent fail to reap the benefit from the greater 
availability of credit. Moreover, financial development is accompanied by financial instability, which disproportionately hurts the poor. Nevertheless, the benefits of financial development for the poor are found to outweigh the cost. Claessens and Feijen (2006) examine the role of financial sector development in achieving Millennium Development Goal targets. They find that financial development and greater access to financial services indeed lead to income growth, a reduction in poverty and undernourishment, and better health, education and gender equality. Honohan (2004) finds that financial sector development is negatively associated with headcount poverty, with a coefficient suggesting that a 10-percentage point change in the ratio of private credit to GDP should reduce poverty ratios by 2.5 to 3 percentage points. Beck et al. (2004), while using data on 52 developing and developed countries to assess the relationship between financial development and income distribution, find that income of the lowest quintile grows faster than the average GDP per capita and income inequality falls more rapidly. Jalilian and Kirkpatrick (2002) employ a pooled panel data approach to examine the link between financial development and poverty reduction using data from a sample of 26 countries, including 18 developing countries. Their results suggest that a 1 percent change in financial development raises growth in the incomes of the poor in developing countries by almost 0.4 percent. Building on earlier research, Jalilian and Kirkpatrick (2005) use a pooled panel data approach to examine the contribution of financial development to poverty reduction in 42 countries, including 26 developing countries. The empirical results indicate that up to a certain threshold level of economic development, financial sector growth contributes to poverty reduction through the growth-enhancing effect. The impact of financial development on poverty reduction will be affected, however, by any change in income inequality resulting from financial development. Li et al. (1998), based on the data from 49 developed and developing countries for the period of 1947 to 1994, find that financial depth is associated with lower levels of inequality.

\section{ESTIMATION TECHNIQUES AND EMPIRICAL ANALYSIS}

\section{Data Source and Definition of Variables}

\section{Data Sources}

Annual time series data, which cover the period between 1978 and 2008, have been used in this study. All the data used in this study were obtained from the various issues of International Financial Statistics (IFS) Yearbook and World Development Indicators.

\section{Definitions of Variables}

\section{Poverty Reduction Proxy (POV)}

The current study uses per capita consumption as a proxy for poverty reduction. This proxy has also been used by Quartey (2005) and Odhiambo (2009b), amongst others.

\section{$\underline{\text { Financial Development Proxies }}$}

Two proxies have been used to measure financial development in this study; namely, the ratio of bank claims on the private sector to GDP (DCP/GDP) and the ratio of broad money stock to gross domestic product (M2/GDP). The DCP/GDP indicates the importance of the role played by the financial sector in the economy. It is assumed that credit provided to the private sector generates increases in investment and productivity to a much larger extent than does credit to the public sector (see Kar and Pentecost, 2000; Odhiambo, 2007). Higher levels of DCP/GDP are interpreted as higher levels of financial services and, therefore, greater financial development (see Seetanah, 2008). The M2/GDP, on the other hand, shows the real size of the financial sector of a growing economy. The ratio is expected to increase over time if the financial sector develops faster than the real sector on the one hand, and to decrease if the financial sector develops more slowly than the real sector, on the other hand (see also Odhiambo, 2008). 


\section{Stationarity Tests}

Although the bounds test for cointegration does not require that all variables be integrated of order 1 [I(1)], it is important to conduct the stationarity tests in order to ensure that the variables are not integrated of order 2 [I(2)]. When the variables are integrated of order 2, the F-test will be spurious because both the critical values of the Fstatistics computed by Pesaran et al (2001) and Narayan (2005) are based on the assumption that the variables are $\mathrm{I}(0)$ or $\mathrm{I}(1)$.

The results of the stationarity tests in levels (not presented here) show that all variables are non-stationary. Having found that the variables are not stationary in levels, the next step is to difference the variables once in order to perform stationarity tests on differenced variables. The results of the stationarity tests on differenced variables are presented in Table 1.

Table 1: Stationarity Tests of Variables on first Difference - Phillips-Perron (PP) and GF-GLS Tests

\begin{tabular}{|l|c|c|}
\hline \multicolumn{1}{|c|}{ Variable } & No Trend & Trend \\
\hline Stationarity Tests of Variables on first Difference - Phillips-Perron (PP) Test & $-5.60021 * * *$ \\
\hline DLPOV & $-5.68568 * * *$ & $-8.92751 * * *$ \\
\hline DLM2/GDP & $-8.64205 * * *$ & $-4.34406 * * *$ \\
\hline DLDCP/GDP & $-4.44189 * * *$ & $-5.59077 * * *$ \\
\hline Stationarity Tests of Variables on first Difference - Dickey-Fuller - GLS Test & $-8.39997 * * *$ \\
\hline DLPOV & $-5.43633 * * *$ & $-4.55143 * * *$ \\
\hline DLM2/GDP & $-7.41380 * * *$ & $-17752 * * *$ \\
\hline DLDCP/GDP & -4.1770 \\
\hline
\end{tabular}

Notes:

1) The truncation lag for the PP tests is based on Newey and West (1987) bandwidth.

2) $* * *$ denotes $1 \%$ level of significance.

3) Critical values for Dickey-Fuller GLS test are based on Elliot-Rothenberg-Stock (1996, Table 1).

\section{Cointegration Test - ARDL Bounds Testing Procedure}

In order to test for the existence of cointegration between each of the two proxies of financial development and the poverty reduction proxy, we apply the recently developed Autoregressive Distributed Lag (ARDL)-bounds testing approach. The ARDL modelling approach was originally introduced by Perasan and Shin (1999) and later extended by Perasan et al. (2001). The ARDL model used in this study can be expressed as follows:

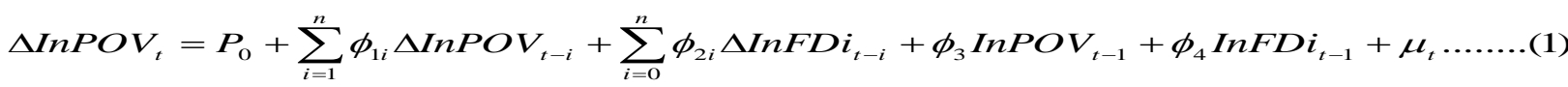

$$
\begin{aligned}
& \Delta \operatorname{InFDi} i_{t}=\delta_{\mathrm{o}}+\sum_{i=1}^{n} \delta_{1 i} \Delta \operatorname{InFDi_{t-i}}+\sum_{i=0}^{n} \delta_{2 i} \Delta \operatorname{InPOV} V_{t-i}+\delta_{3} \operatorname{InPO} V_{t-1}+\delta_{4} \operatorname{In} F D i_{t-1}+\mu
\end{aligned}
$$

where InPOV $=\log$ of poverty reduction variable; InFDi = log of financial development proxies; namely, the ratio of broad money supply to GDP (M2/GDP) and the ratio of domestic private sector credit to GDP (DCP/GDP); $\mu_{\mathrm{t}}=$ white noise error term; and $\Delta=$ first difference operator.

The bounds testing procedure is based on the joint F-statistic (or Wald statistic) for cointegration analysis (see also Odhiambo, 2010a). The asymptotic distribution of the F-statistic is non-standard under the null hypothesis of no cointegration between the examined variables. In the bounds test procedure, the null hypothesis of no cointegration among the variables in equations (1) and (2) is tested against the alternative hypothesis. Pesaran et al. (2001) report two sets of critical values for a given significance level. One set of critical values assumes that all variables included in the ARDL model are $\mathrm{I}(0)$, while the other is calculated on the assumption that the variables are I(1). If the computed test statistic exceeds the upper critical bounds value, then the Ho hypothesis is rejected. If the F-statistic falls into the bounds, then the cointegration test becomes inconclusive. If the F-statistic is lower than the lower bounds value, then the null hypothesis of no cointegration cannot be rejected. 
The ARDL-bounds testing procedure involves two steps. In the first step, the order of lags on the first differenced variables in equations (1) and (2) is obtained from the unrestricted models by using the Akaike Information Criterion (AIC) and the Schwartz Bayesian Criterion (SBC). The results of the AIC and SBC tests (not reported here) show that when M2/GDP is used as a proxy for financial development, the optimal lag is found to be 2. However, when the DCP/GDP is used as a proxy for financial development, the optimal lag is found to be 1 . This means that our selected lag lengths for M2/GDP and DCP/GDP are lags 2 and 1, respectively. In the second step, we apply the bounds F-test to equations (1) and (2) in order to establish whether there exists any long-run relationship between the variables under study. The results of the bounds test are reported in Table 2.

Table 2: Bounds F-test for Cointegration

\begin{tabular}{|c|c|c|c|c|c|c|}
\hline Dependent variable & \multicolumn{3}{|c|}{ Function } & \multicolumn{3}{|c|}{ F-test statistic } \\
\hline POV & \multicolumn{3}{|c|}{ POV(M2/GDP) } & \multicolumn{3}{|c|}{1.3800} \\
\hline M2/GDP & \multicolumn{3}{|c|}{$\mathrm{M} 2 / \mathrm{GDP}(\mathrm{POV})$} & \multicolumn{3}{|c|}{$9.8313 * * *$} \\
\hline POV & \multicolumn{3}{|c|}{ POV(DCP/GDP) } & \multicolumn{3}{|c|}{1.4164} \\
\hline DCP/GDP & \multicolumn{3}{|c|}{ DCP/GDP(POV) } & \multicolumn{3}{|c|}{$4.087 *$} \\
\hline \multicolumn{7}{|c|}{ Asymptotic Critical Values } \\
\hline & \multicolumn{2}{|c|}{$1 \%$} & \multicolumn{2}{|c|}{$5 \%$} & \multicolumn{2}{|c|}{$10 \%$} \\
\hline & $\mathrm{I}(0)$ & $\mathrm{I}(1)$ & $\mathrm{I}(0)$ & $\mathrm{I}(1)$ & $\mathrm{I}(0)$ & $\mathrm{I}(1)$ \\
\hline $\begin{array}{l}\text { Pesaran et al (2001), p. 300, Table CI(ii) } \\
\text { Case II }\end{array}$ & 4.94 & 5.58 & 3.62 & 4.16 & 3.02 & 3.51 \\
\hline
\end{tabular}

Note: $*$ denotes statistical significance at the $10 \%$ level.

The results reported in Table 2 show that when the monetization variable (M2/GDP) is used as a proxy for financial development, the calculated F-statistic is found to be higher than the upper-bound critical value in the M2/GDP equation, but not in the poverty reduction (POV) equation. Likewise, when the domestic credit to the private sector (DCP/GDP) is used as a proxy for financial development, the calculated F-statistic is found to be higher than the upper-bound critical value in the DCP/GDP equation, but not in the poverty reduction equation. This, therefore, shows that there is a unique cointgeration vector between POV and M2/GDP, as well as between POV and DCP/GDP.

\section{Granger Non-Causality Test}

Once the long-run relationships have been identified, the next step is to examine the Granger-causality between the two proxies of financial development and the poverty reduction proxy. The direction of the Grangercausality between the two proxies of financial development; i.e., M2/GDP and DCP/GDP and the poverty reduction proxy (POV), can be tested using the following model (see Odhiambo, 2010a; Narayan and Smyth, 2008).

$$
\begin{aligned}
& \triangle \operatorname{InPOV} V_{t}=\phi_{\mathrm{O}}+\sum_{i=1}^{n} \phi_{1 i} \Delta \operatorname{InPO} V_{t-i}+\sum_{i=0}^{n} \phi_{2 i} \Delta \operatorname{InFDi}_{t-i}+\mathrm{ECM}_{t-1}+\mu_{t} \ldots \ldots . .(7) \\
& \triangle \operatorname{InFDi}_{t}=\delta_{\mathrm{O}}+\sum_{i=1}^{n} \delta_{1 i} \Delta \operatorname{InFD} i_{t-i}+\sum_{i=0}^{n} \delta_{2 i} \Delta \operatorname{InPOV} V_{t-i}+\operatorname{ECM}_{t-1}+\mu_{t} \ldots \ldots \ldots \ldots \ldots . . . .(8)
\end{aligned}
$$

where $\mathrm{ECM}_{\mathrm{t}-1}=$ the lagged error-correction term obtained from the long-run equilibrium relationship.

Although the existence of a long-run relationship between the proxies of financial development and poverty reduction suggests that there must be Granger-causality in at least one direction, it does not indicate the direction of temporal causality between the variables. The direction of the causality, in this case, can only be determined by the F-statistic and the lagged error-correction term. The F-statistic on the explanatory variables, in this case, represents the short-run causal effect, while the t statistic on the coefficient of the lagged error-correction term represents the long-run causal relationship (see Odhiambo, 2010a; Narayan and Smyth, 2005). The results of these causality tests are reported in Table 4. 
Table 4: Granger Non-Causality Tests

\begin{tabular}{|c|c|c|c|c|}
\hline \multicolumn{5}{|c|}{ Model 1 - Poverty Reduction (POV) and Monetization Variable (M2/GDP) } \\
\hline $\begin{array}{c}\text { Dependent } \\
\text { Variable }\end{array}$ & Causal Flow & F-Statistic & t-Test on ECM & $\mathbf{R}^{2}$ \\
\hline Poverty reduction $(\mathrm{POV})$ & $\begin{array}{l}\text { Monetization variable }(\mathrm{M} 2 / \mathrm{GDP}) \rightarrow \\
\text { Poverty reduction }(\mathrm{POV})\end{array}$ & $\begin{array}{c}5.2303 \\
{[0.0044] * * *}\end{array}$ & - & 0.76 \\
\hline $\begin{array}{l}\text { Monetization variable } \\
\text { (M2/GDP) }\end{array}$ & $\begin{array}{l}\text { Poverty reduction }(\mathrm{POV}) \rightarrow \text { Monetization } \\
\text { variable }(\mathrm{M} 2 / \mathrm{GDP})\end{array}$ & $\begin{array}{c}8.77 \\
{[0.0135]^{* * *}}\end{array}$ & $\begin{array}{l}-0.67 * * * \\
{[-3.802]}\end{array}$ & 0.94 \\
\hline Poverty reduction (POV) & $\begin{array}{l}\text { Domestic credit to the private sector } \\
(\mathrm{DCP} / \mathrm{GDP}) \rightarrow \text { Poverty reduction (POV) }\end{array}$ & $\begin{array}{c}5.8162 \\
{[0.0120]^{* * *}} \\
\end{array}$ & - & 0.66 \\
\hline $\begin{array}{l}\text { Domestic credit to the } \\
\text { private sector } \\
\text { (DCP/GDP) }\end{array}$ & $\begin{array}{l}\text { Poverty reduction }(\mathrm{POV}) \rightarrow \text { Domestic } \\
\text { credit to the private sector }(\mathrm{DCP} / \mathrm{GDP})\end{array}$ & $\begin{array}{c}5,9376 \\
{[0.0149]^{* * *}}\end{array}$ & $\begin{array}{c}-0.22 \\
{[-1.522]}\end{array}$ & 0.87 \\
\hline
\end{tabular}

The empirical results reported in Table 4 show that the causal relationship between financial development and poverty reduction in China is sensitive to the proxy used to measure the level of financial development. When the monetization variable (M2/GDP) is used as a proxy for financial development, a bidirectional causality between financial development and poverty reduction is reported in the short run, but a unidirectional causality from poverty reduction to financial development is found to prevail in the long run. The short-run finding is supported by the Fstatistic in both the M2/GDP and DCP/GDP equations, which are both statistically significant. The long-run causality, on the other hand, is supported by the coefficient of the lagged error-correction term in the M2/GDP, which is negative and statistically significant - as expected. However, when the DCP/GDP is used as a proxy for financial development, only a short-run bidirectional causality is found to prevail between financial development and poverty reduction. This finding is confirmed by the F-statistics in both POV and DCP/GDP equations, which are both statistically significant.

\section{CONCLUSION}

This paper has examined the direction of causality between financial development and poverty reduction in China using the 1978-2008 data. Unlike the majority of the previous studies, the current study has used the newly developed ARDL-Bounds testing approach by Pesaran et al. (2001) to examine this linkage. The study has used two proxies of financial development; namely, the monetization variable (M2/GDP) and the domestic credit to the private sector as a ratio of GDP (DCP/GDP) to examine this linkage. The poverty reduction, on the other hand, has been proxied by the private per capita consumption. The empirical results of this study show that the causal relationship between financial development and poverty reduction in China is sensitive to the proxy used for measuring the financial development. When the domestic credit to the private sector is used as a proxy for financial development, both financial development and poverty reduction are found to Granger-cause each other in the short run. However, when the broad money supply ratio (M2/GDP) is used as a proxy for financial development, poverty reduction Granger-causes financial development, both in the short run and in the long run, but financial development only Granger-causes poverty reduction in the short run. These results show that the poverty-reduction programmes which have been ongoing in China for decades - are likely to lead to further development of the financial sector in the long run.

\section{AUTHOR INFORMATION}

Sin-Yu Ho received both her Bachelor's degree and Master's degree in Economics from the University of Hong Kong. She is currently working as a lecturer in the Economics Department at the University of South Africa (UNISA). Before joining UNISA in 2009, she worked for the University of Hong Kong, where she was responsible for teaching courses related to microeconomic theory, macroeconomic theory, and economics of China. She has a research interest in macroeconomics and China's economic development. Email: hosy@unisa.ac.za

Prof Nicholas M Odhiambo holds a PhD (Economics) degree from Stellenbosch University (South Africa) and a Masters degree in Economics from the University of Dar-es-salaam (Tanzania). Prof Odhiambo's research profile is broad, rich and multifaceted. During the past ten years, he has published more than 50 articles in 25 recognised 
journals. Prof Odhiambo is an NRF-rated researcher, and is listed in a number of international bibliographies and databases. Prof Odhiambo is currently working as Professor of Economics and Chair of Growth, Poverty and Policy Modelling (GPPM) Research flagship at the University of South Africa (UNISA). Email: odhianm@unisa.ac.za

\section{REFERENCES}

1. Akhter, S., Liu, Y. and Daly, K., 2010, "Cross country evidence on the linkages between financial development and poverty", International Journal of Business and Management, Vol. 5, No. 1.

2. Allen, F., Qian J. and Qian M., 2005, "China's financial system: past, present and future", China's Great Economic Transformation, edited by Loren Brandt and Thomas Rawski, Cambridge University Press

3. Beck, T., Demirguc-Kunt, A. and Levine, R., 2004, "Finance, inequality and poverty: cross-country evidence", World Bank Policy Research Working Paper 3338.

4. Bittencourt, M. M., 2010, "Financial development and inequality: Brazil, 1985-1994", Economic Change and Restructuring, Vol. 43, No. 2, pp 113-130

5. $\quad$ Burgess, R. and. Pande, R., 2005, "Do rural banks matter? Evidence from the Indian social banking experiment." American Economic Review Vol. 95, No. 3 pp780-95.

6. Claessens, S. and Feijen, E., 2006, "Financial sector development and the millennium development goals", World Bank Working Paper No. 89, World Bank, Washington, DC.

7. Engle, R.F. and Granger, C.J., 1987, "Cointegration and error-correction representation, estimation and testing", Econometrica 55 (2): 251-78.

8. Geda A., Shimeles, A. and Zerfu D., 2006, "Finance and poverty in Ethiopia", UNU-WIDER Research Paper No. 2006/51, United Nations University, Helsinki, Finland.

9. Hao, C., 2006, "Development of financial intermediation and economic growth: the Chinese experience", China Economic Review, Vol. 17, pp.347 - 362

10. Hasan, I. and Zhou, M., 2006, "Financial sector development and growth: the Chinese Experience", WIDER Research Paper, Vol: 2006/85

11. Honohan, P., 2004, "Financial development, growth and poverty": How close are the links?, in C. Goodhart (ed.), Financial Development and Economic Growth: Explaining the Links, Busingstoke: Palgrave Macmillan.

12. Husain, I., 2004, "Financial sector reforms and pro-poor growth: Case study of Pakistan." Presidential Address at the Annual General Meeting of the Institute of Bankers Pakistan, Karachi, 21st February, 2004.

13. Jalilian, H. and Kirkpatrick, C., 2002, "Financial development and poverty reduction in developing countries", International Journal of Finance and Economics, Vol. 7, No. 2, pp 97-108

14. Jalilian, H. and Kirkpatrick, C., 2005, "Does financial development contribute to poverty reduction?" Journal of Development Studies, Vol. 41, No. 4, pp. 636-656.

15. Jeanneney, S.G. and Kpodar, K., 2005, "Financial development, financial instability and poverty", Working Paper, CSAE WPS/2005-09, University of Auvergne

16. Jeanneney, S.G. and Kpodar, K., 2008, "Financial development and poverty reduction: Can there be a benefit without a cost?", IMF Working Paper, WP/08/62. IMF, African Department.

17. Jiang, S. and Yan, Y., 2006, "A study on effectiveness of civilian credit in anti-poverty in China rural area", Journal of Finance and Economics; 2006-10.

18. Johansen, S. and Juselius, K., 1990, "Maximum likelihood estimation and inference on cointegration with applications to the demand for money", Oxford Bulletin of Economics and Statistics 52:169-210.

19. Kar, Muhsin and Pentecost, E.J., 2000, "Financial development and economic growth in Turkey: Further evidence on the causality issue", Economic Research Paper No.00/27, Department of Economics, University of Loughborough University.

20. Li, H., Squire, L. and Zou, H., 1998, "Explaining international and intertemporal variations in income inequality." Economics Journal 108, pp 26-43.

21. Narayan, P.K., 2005. "The saving and investment nexus for china: evidence from cointegration tests". Applied Economics 37, 1979-1990

22. Narayan, P.K. and Smyth, R., 2005, "Electricity Consumption, Employment and Real Income in Australia: Evidence from Multivariate Granger Causality Tests", Energy Policy 33: 1109-1116.

23. Narayan, P.K. and Smyth, R., 2008, "Energy consumption and real GDP in G7 countries: New evidence from panel cointegration with structural breaks", Energy Economics 30, 2331-2341. 
24. Odhiambo, N.M., 2007, "Supply-leading versus demand-following hypothesis: Empirical evidence from three SSA Countries", African Development Review, Vol. 19, Issue 2.

25. Odhiambo, N.M., 2008, "Financial depth, savings and economic growth in Kenya: A dynamic causal linkage", Economic Modelling 25(4), 704-713.

26. Odhiambo, N.M., 2009a, "Energy consumption and economic growth in Tanzania: An ARDL-bounds testing approach", Energy Policy, Vol. 37, Issue 2.

27. Odhiambo, N.M., 2009b, "Finance-growth-poverty nexus in South Africa: a dynamic causality linkage", The Journal of Socio-Economics, Vol. 38, pp. 320-325.

28. Odhiambo, N.M., 2010a, "Financial deepening and poverty reduction in Zambia: an Empirical Investigation", International Journal of Social Economics, Vol. 37, pp. 41-53.

29. Odhiambo, N.M., 2010b, "Is Financial Development a Spur to Poverty Reduction? Kenya's Experience”, Journal of Economic Studies, Vol. 37, Issue 4.

30. Park, A., Ren, C. and Wang, S., 2004, "Micro-finance, poverty alleviation, and financial reform in China", Rural Finance and credit infrastructure in China, OECD, pp.256- 270

31. Pesaran, M. and Shin, Y., 1999, “An autoregressive distributed lag modeling approach to cointegration analysis" in S. Strom, (ed) Econometrics and Economic Theory in the 20th Century: The Ragnar Frisch centennial Symposium, Cambridge University Press, Cambridge.

32. Pesaran, M., Shin, Y. and Smith, R., 2001, "Bounds testing approaches to the analysis of level relationships", Journal of Applied Econometrics 16, 289-326.

33. Quartey P., 2005, "Financial sector development, savings mobilisation and poverty reduction in Ghana", UNU-WIDER Research Paper No. 2005/71, United Nations University, Helsinki, Finland.

34. Seetanah, B., 2008, "Financial development and economic growth: An ARDL approach for the case of the small island state of Mauritius", Applied Economics Letters 15, pp. 809-813.

35. Stiglitz, J., 1998, "The role of the state in financial markets", Proceedings of the World Bank Annual Conference on Development Economic, pp. 19-52.

36. UNDP, 2008, Human Development Report: China 2007/2008, United Nations Development Programme.

37. World Bank, 2001, World Development Report 2000/2001, Oxford University Press, New York.

38. World Bank, 2004, "The 8-7 National Poverty Reduction Program in China - The National Strategy and Its Impact", World Bank.

39. World Bank, 2009, "From poor areas to poor people: China's evolving poverty reduction Agenda. An assessment of poverty and inequality in China", The World Bank, East Asia and Pacific Region.

40. World Development Indicators 2009, World Bank, Washington, D.C. 


\section{NOTES}

